Mid-American Review of Sociology

Shibutani, T.

1972 "Reference Groups as Perspectives." In J.G. Manis and B.N. Meltzer eds., Symbolic Interaction. Boston: Allyn and Bacon, Inc.

Shifflet, P.A.

1976 "Folklore and Food Habits." Journal of the American Dietetic Association 68:347-350.

Sjoberg, $\mathrm{G}$. and Nett, $\mathrm{R}$.

1968 A Methodology for Social Research. New York: Harper and Row, Publishers.

Stebbins, R.A.

1972 "Studying the Definition of the Situation: Theory and Field Research Strategies." In J.G. Manis and B.N.Meltzer eds., Symbolic Interaction. Boston: Allyn and Bacon, Inc.

Wilson, C.S.

1971 "Food Beliefs Affect Nutritional Status of Malay Fisherfolk." Journal of Nutrition Education (Winter):96-98.

Yetley, E.

1977 Personal Correspondence.

Zaner, R.

1970 The Way of Phenomology: Criticism as a Philosophical Discipline. New York: Pegasus.

1973 "Solitude and Sociality: The Critical Foundations of the Social Sciences." In G. Psathas ed., Phenomenological Sociology: Issues and Applications. New York: Wiley.

Zimmerman, D. and Wieder, D.L.

1977 "The Diary: Diary-Interview Method." Urban Life 5:479-498.

\section{LABELING AND OPPRESSION: WITCHCRAFT IN MEDIEVAL EUROPE}

\author{
Mary Ann Campbell \\ Washington University
}

Mid-American Review of Sociology, Vol. III, No. 2:55-82

The attempt here is to understand the social conditions and processes through which witches were labeled, hunted and persecuted in Europe during the Middle Ages. An historical analysis, utilizing anthropological accounts, Church doctrines and handbooks from the Inquisition, as well as testimonies, notes and sentences from witch trials, identifies the Church as labeler and the witch as rule-breaker. Throughout Church proclamations and convicting testimonies, there run three strands of indictment against witches: they did not worship the Christian God; they used magical powers to help or harm people; and they threatened or harmed men sexually. It is shown how these witches, many of whom were peasant healers, represented threats to the entrenchment of the Church, the legitimation of medicine as an honorable profession, and the perpetuation of patriarchal authority. It is submitted that the witch-image was created by the Christian Church, with support from secular rulers and "professional" medical practitioners, to eradicate persistent pagan religions and lay healing practices, including midwifery. This image of woman as evil incarnate, and the accompanying sex oppression, has persisted through the centuries. Modern-day implications of the witch-image are discussed in light of the current women's culture movement.

The topic of concern in this paper, witchcraft in medieval Europe, has not to my knowledge benefited from close examination of an explicitly sociological nature. There is as yet no competing body of explanations for the phenomenon, or much discussion of it in sociological literature. The subject has been explored by historians and cultural anthropologists, the latter mainly in terms of the social cohesion function of ritual and belief in magic. Medical treatises mention it as "primitive" or "unscientific" healing, while the psychiatric approach has been to 
dismiss it as a manifestation of widespread madness characterized by hysteria and delusion. ${ }^{1}$ Historical treatments have provided a great deal of documentation of the persecution of witches, however, and a sociological examination of this phenomenon can be insightful.

Specifically, the attempt here is to understand the social conditions and the social processes under which witches were labeled, hunted and persecuted in Europe during the Middle Ages. The reader might keep in mind that this mass execution is the focus of the investigation at hand and constitutes a major historical and cultural difference between the medieval European expression of the witch phenomenon and others, such as the witch trails held somewhat later in England and New England, third world witch beliefs and customs and the present-day witch cults in the Americas and Europe. Limitations of time and space require this narrowing of the topic, ${ }^{2}$ but its thorough investigation can contribute to a larger historical analysis of the phenomenon of witchcraft. As part of such a pursuit, I will try to portray not only the relationship between those who were labeled as witches and those who did the labeling, but also the structural relationships of the institutions which sanctioned this labeling process and used the label of witch to legitimate the extermination of peasant healers.

\section{The Labeling of Witches in Medieval Europe}

Using Becker's (1973:8) definition of deviance as "the infraction of some agreed upon rule," we can describe witches as rule breakers, as deviants. But we cannot understand this deviance except against the background of the social fabric of the period. Throughout much of the historical material on witchcraft, especially Church proclamations and convicting testimonies, there run three strands of indictment against witches: 1) they did not worship the Christian God;2) they used magical powers to help or harm people; and 3) they threatened or harmed men sexually (Sprenger and Kramer, 1928:xliii-xlv; Summers, 1956:13-32). In other words, the label of witch seems to have been applied to those who allegedly violated norms of institutionalized religion and medicine, and of the role of women in patriarchal society. A historical picture of the emergence of the institutions of professional medicine and the Christian Church as they developed within the context of patriarchal feudalism might contribute to an explanation of the labelers and the deviants.

Most of those labeled as witches during the Inquisition were peasants, mainly women. Many were old women and women living alone or in groups. Many of these women were lay healers who practiced midwifery and herbal medicine, as well as healing by charms and spells. Many of the witches were women and men who followed the ancient pagan religions, worshiping nature through the adoration of many gods, rather than the one "true" Christian God. The pagan rituals were hedonistic, characterized by feasting, dancing, and joyous celebration. Many of these rituals included sexual acts; some involved human sacrifice. These rituals were widespread and predated Christianity, as did the recipes for herbal "cures" which had been passed down through generations before "modern medicine" made an attempt to invent itself (Cohn, 1970:11-13; Ehrenreich and English, 1973:12-20). It appears that one need fit only one of the categories listed above (pagan, peasant, healer, female) to be branded a witch, but a combination of stigmas was deadly.

The ultimate feudal rule makers were the royalty and the aristocracy. But the centuries immediately preceding the Inquisition saw a consolidation of power by the Christian Church which culminated in the Pope enjoying a unique sort of moral despotism (Lea, 1906, v. I:1-56). Thus, the Church also was a rule maker in the feudal era, especially because it came to own a great deal of land and wealth. Furthermore, the Church served as the rule enforcer through its local ecclesiastics and through secular officials, judges, and politicians "owned" by the Church (Murray, 1921:19-27; Lea, 1906, v. I:534-541, v. III:181-334; Sprenger and Kramer, 1928:194-205).

In addition to the Church-appointed Inquisitors, there developed an entire class of enterprising witch-finders equipped with special talents, psychic powers, tests and accoutrements. 
These witch-finders often made money by extorting ignorant peasants who were deathly afraid of finding out they were witches by means of some bounty hunter's "test". Traveling vendors made even more money by selling indulgences to the repentant and faithful at exorbitant prices (Lea, 1906, v. I:41-47).

Besides literally capitalizing on the witch-craze, medieval rule makers and enforcers stood to gain substantial prestige and social power. Ehrenreich and English (1973) suggest such goals underlay the great interest of the infant medical science in stamping out those women who were healing people without the benefit of recently instituted university degrees or "modern" methods, such as bleeding and the use of leeches (Murray, 1952:145). By joining the Church in persecuting lay healers, "licensed" physicians could criticize the superstitions, spells and charms used by peasant women healers, thereby diverting criticism from their own suspect methods. The plan seems to have been to achieve a sort of legitimation by default while creating a monopoly on rural clients, many of whom would plausibly have taken their chances with no medical help rather than with a "licensed" physician of the time.

To summarize the major point of this paper, I would submit the following:

(1) The witch-image as we know it today was created by the Christian Church as one of the means of entrenching itself as the one true religion of the Western world.

(2) The Church gained virtually boundless political power by first cooperating with and then subduing secular authority, and through the agency of the Inquisition attempted to eliminate present challenges and prevent future challenges to that power.

(3) Although the mythology of witches as possessed by the Devil was created by the Church, it was based on distortions of real beliefs and practices of the pagan religions.
(4) The Church utilized a process of labeling priestesses of the Old Religion as deviants; imposing force to wipe them and their followers out; and broadening the definition of the witch and the scope of the oppression within the context of the institutionalized abomination known as the Inquisition. In so doing, Christianity successfully drove paganism underground and inscribed an indelible fear of the Devil in the hearts and minds of the masses, whom it purported to protect from this evil.

I have set forth my conclusions first, so that the reader can keep them in mind while following the interpretation of "evidence" which will be presented in roughly chronological order, the better to picture the historical and social relationships of institutionalized power. Support for the thesis is drawn from anthropological and historical accounts, theological tracts of the period as well as pertinent contemporary essays, Church doctrines and handbooks from the Inquisition, and testimonies, notes and sentences from witch trials. Because of the nature of this documentation, I rely heavily on quotations. This is especially the case since many are secondary sources, being translations from German, French, and Latin or quotes from works which are out of print or not easily accessible. The quotes selected for illustration in most cases exemplify or highlight material found in two or more sources.

It should also be mentioned that an attempt is made to emphasize the actual works of the Christian Church and the medical profession, and to demonstrate agreement on certain points by various authors. When all is said and done, this piece comprises no more than a sketch of historical shadows embellished by a political explanation based on underlying values to which I freely admit.

Unfortunately, the witch herself-poor and illiterate-did not leave us her story. It was recorded, like all history, by the educated elite, so that today we know the witch only through the eyes of her persecutors (Ehrenreich and English, 1973:8). 


\section{The Old Religion}

There seems to be a good deal of interdisciplinary agreement on the historicity of witch-beliefs:

From the earliest period of which we have records, there have been practitioners of magic, credited with the powers of divination, of control over the laws of nature and of intercourse with the spirit world (Pratt, 1915:18).

Some anthropologists go so far as to say:

There is, however, a continuity of belief and ritual which can be traced from the Paleolithic period down to modern times (Murray, 1952:1-12).

In classical Greece, it was believed that the witches (priestesses) received their power directly from the gods and goddesses. Hecate, the patroness of witches, was worshipped universally in Greece and statues of her were consulted as oracles. Her priestesses were skilled in magical arts which included making salves, molding effigies, and the use of poisons. They were also considered to be very wise. The Greeks regarded the famous witches of Thessaly as being most learned. Diana was the Roman counterpart of Hecate, and her witches were also much honored and consulted (Pratt, 1915; Cohn, 1970; Russell, 1972).

From the decline of the Roman Empire to the rise of Christianity, various pagan religions flourished throughout Europe. The Vandals, Goths and Huns are dismissed in history books as the barbarian hordes who overran the Roman Empire, who destroyed a well-developed culture. Little attention is given to the culture of these peoples, or to their primitive religions which, like the Greeks and Romans, included beliefs in magical acts (the Crafte of the Wise) performed by priestesses (Wiccan). We are not usually informed that:
Historically, the Crafte of the Wise existed for thousands of years as the religion of the people throughout Europe, led by a sisterhood of priestesses who were sometimes trained within a sacred college of women or on one of the women's islands described by Strabo and Pomponius Mela. The priestesses were the Wise Women who performed rites for bringing prosperity to the land and the people, acted as seers, and were the healers (McFarland, 1975:42).

The Ostrogoths in Italy, the Visigoths in Spain and France, the Franks and Gauls in France, the Saxons and Druids in England and Scotland, the Druidic Celts who settled in Gaul, and the Teutonic tribes of the Baltic all had priestesses of what is now referred to as the Old Religion (Dawson, 1935; Cohn, 1970; Murray, 1952). Their traditions were inherited from the early pagan religions of the Paulicians, Bogomiles, Kathari, Paterini, Vaudois, Albigensis, Tartarins, Beghards, and Priscillians (Summers, 1927).

The Old Religion can be characterized as nature worship, with dieties often appearing in the form of animals. The faithful may have dressed themselves in the skins and horns of various sacred animals to represent or become closer to their gods. Rituals offered thanks for nature's provision of food and the necessities of life. Many rituals featured animal sacrifice, and sometimes there was human sacrifice. Sexual acts were an integral part of many rituals, as was the use of naturally occurring drugs. Often the religious ceremonies were held at night and were followed by feasting and celebration. This relationship between hedonism and religion, as we shall see, was to be stamped out by ascetic Christianity.

\section{The Rise of Christianity}

Pratt (1915:28) reminds us that "European Christianity existed for centuries side by side with paganism." But this was not a peaceful co-existence. The Christian Church was in the process of consolidating power, a process which involved a broad 
campaign of "conversion," the seizure of territory, and the formation of alliances with secular rulers.

During the first eight centuries A.D., the Christian Church was institutionalizing itself. In so doing, it faced some difficulty in converting pagans. The task, as Summers states it, was

...to replace the primitive and seemingly natural conception of life by an entirely different one which appeared strange to the people, who for a long while regarded the new ideas not only with mistrust, but also with a certain contempt especially hard to eradicate and overcome (1927:465).

The Church was able to win superficial converts; that is, the overpowered pagans conformed outwardly to the norms of Christianity. But many continued to practice their own religion secretly (as the followers of Jesus had done earlier), especially in the countryside. Some pagan customs were absorbed into the Church, such as the fertility rite observed on December 25 which became incorporated into Christmas celebrations (Russell, 1921:51).

It is evident from Church proclamations that there was a problem with even Christian priests utilizing pagan spells and charms; various provincial councils decreed not only that pagan customs and rites should not be practiced, but especially that Christian priests should not be practicing them. Later declarations specify defrocking or excommunication for priests who practiced or consulted the Crafte of the Wise.

\section{Society Creates Deviance: The Church Creates the Witch}

The preceding discussion of the Old Religion and the rise of Christianity serves to highlight a historical fact which has frequently been ignored in analysis of the witch phenomenon: the negative image of witch as evil, as deviant, was created by the Christian Church with the help of the secular ruling class. The "One True Church" had to eliminate its competition. At first this was done by simply outlawing other religions, proclaiming their believers and priestesses to be anathema. Such proclamations increased as the Church felt the depth of enculturation of the pagans and the popularity of pagan rites.

Thus, in its initial phase of consolidation of power (until about the ninth century) the Church attempted to "regulate out" any other religion. The thrust of its doctrine during this period was that people should not believe in witches. Rather, they should put their faith in the Father, Son and Holy Ghost. The Church outlawed those pagans who would not be Christians and punished those Christians who would be pagans. In short, the Church attempted to define the boundaries of legitimate religious belief.

\section{Labeling and Power: Church and State}

The Church developed very good working relations with certain secular rulers, a good example being Charlemagne. After he was "saved", he tried to Christianize his kingdom. His administrative approach to conversion was to issue an Edict ordering the imprisonment of alleged sorcerers (esses) until they confessed and promised to amend. This case illustrates the growing interdependence of Church and State. As a follower of the faith, the king must accept the pre-eminence of the One True Church. As citizens of the empire, the archpriests had to follow Charlemagne's Edict. State as well as Ecclesiastical means actually were working for ends of the Church.

Similarly, but temporally later, the Laws of King Cnut, promulgated from 1017 to 1035 , specify:

We earnestly forbid every heathenism: heathenism is, that men worship idols; that is; they worship heathen gods, and the sun or the moon, fire or rivers, waterfalls or stones, or forest trees of any kind; or love witchcraft. . .(Murray, 1921:23).

Some interesting cases of Church/State interdependence which appeared at the beginning of the witch-heresy trials are described by Murray. One case described by Murray involved a Catholic priest of Inverkeithing who was presented for punishment 
before the bishop in 1282 for leading a fertility dance around a phallic figure at Easter. The priest was assigned "Hail Mary" duty, but "was allowed to retain his benefice" (Murray, 1921:23).

In 1303, the Bishop of Coventry was accused of membership in a heretical sect. He apparently avoided being executed for his faith in the Old Religion because he was able to convince his judges that he could believe in paganism and Christianity simultaneously. Sociological scrutiny of such a case indicates a reluctance (at the beginning) to sentence to death by ecclesiastical trial and to execute by secular authority a member of the Church hierarchy.

In 1324 a certain Dame Allice Kyteler was tried in the ecclesiastical court of the Bishop of Ossory for the crime of worshiping a diety other than the Christian God. She did not deny the allegation or its "proof," but she was of too high social rank to be condemned. In Nider's Formicarius, Murray finds that the Church was allowed to seize only the poorer members in the investigation at Berne. Those of high rank were "too powerful to be sent to their deaths and went free" (Murray, 1952:177). Similar cases of class bias are apparent in various other reports of trials. Several of the decrees issued by provincial councils and synods specify special treatment for those of high rank. Feudalism was deeply rooted in the ground from which the Church grew, and mutual back-scratching of Church and State is to be inferred.

\section{Institutionalization of the Inquisition}

However, this inference is suitable only for the first of the trials when the Church had not yet gained complete dominance over the ruling classes of Europe. As the Inquisition itself came to be institutionalized, no acquisition of class or social position assured escape from the wrath of God as vented by the Church. A present-day follower of the Old Religion expresses vividly a conception of this wrath:
The Church Militant lit the first torch of the Burning Time and, for the next four hundred years, all deviance from Church-defined norms was punished by death. This death took the form of burning at the stake, strangulation, crushing with stones, whipping, hanging, drowning and unspeakable and vile tortures. In the massive wave of hysteria that plunged humankind into the Dark Ages, it is estimated that nine million women, men and even children were murdered in the name of a patriarchal god whose message was said to be of peace, universal fellowship, and love (McFarland, 1975:44).

The Church had been condemning the pagan healing practices and rituals, but it had not yet accelerated its campaign of terrorism. Students of the subject tend to agree on a change in the dogma of the Church which emerged around the ninth to eleventh centuries, when the Church began to attribute the witches' power to the Devil (Cohn, 1970; Murray, 1952; Pratt, 1915). The label of witch no longer signified simply non-normativeness. It became imbued with a fearsome meaning: evil. The Church abandoned the practice of telling people not to believe in witchcraft and adopted a new strategy. Witchcraft was real indeed, for it was the Devil's work. It was to be dreaded by the people and conquered righteously by the Church.

Although this historical fact of the alteration of the label of witch is admitted by a scholar of the Church, Sister Antoinette Marie Pratt, A.M., she is compelled to give an explanation for it which must find disagreement with a sociological perspective.

With the passing centuries, the question of witchcraft, instead of dying out, came into greater prominence, possibly because heresies began to multiply and many of the heretical practices were mingled with sorcery. Hence we find the Church recognizing the evil and dealing with it accordingly (1915:38).

I would speculate that, rather than an increase in the actual incidence of witchcraft, the main factor influencing Church policy was the change in the views of ecclesiastical writers. Even Sister 
Pratt pegs the Church as transforming the pagan gods into demons and attributing the power of their priestesses to the Devil. Abelard in 1142 even went so far as to propose that God permitted the devil to tempt humans. This proposition had a great influence on thirteenth century theologians (Pratt, 1915:38). Abelard's contribution got the Church, at least to its own satisfaction, out of the problem of whose power is more powerful, God's or Satan's. As theology developed in the eleventh, twelfth and thirteenth centuries, it created what were termed "heretical sects." Members of such sects, of course, never thought of themselves as heretical because they believed in their religion.

It is impossible to understand the witch-cult without first understanding the position of the chief personage of that cult. He was known to the contemporary Christian judges and recorders as the Devil, and was called by them Satan, Lucifer, Beelzebub, the Foul Fiend, the Enemy of Salvation, and similar names appropriate to the Principle of Evil, the Devil of the Scriptures, with whom they identified him.

This was far from the view of the witches themselves. To them, this so-called devil was God, manifest and incarnate; they adored him on their knees, they addressed their prayers to him, they offered thanks to him as the giver of food and the necessities of life, they dedicated their children to him, and there are indications that, like many another god, he was sacrificed for the good of his people (Murray, 1921:28).

From Murray's analysis, we can conclude that the Wiccan did not accept the Church's label. They did not regard themselves as stigmatized, any more than they could regard their gods as demons or their rites as sinful. They had no investment in Christianity or its law. The "glue" which held together their social structure, whether they were nomads or farmers and hunters, was the heritage of paganism.
The Old Religion persisted, and the Church could not afford to go on simply labeling pagans as deviant. It took nine centuries for the Church hierarchy to realize that merely because they decreed paganism anathema, that didn't make it go away. Paganism was very strong and apparently very evident. Its visibility was enhanced by two interesting factors: the Wicca were actively practicing healing with magic as well as "home remedies," and despite attempts of the Church to prevent it, large numbers of priests seem to have had more faith in the Crafte of the Wise than in certain acceptable Christian beliefs (Pratt, 1915:32-37).

Having suggested that pagans of the Old Religion didn't at this point accept a deviant identity, and that there was a gap between Church dogma and the practices of local priests and parishioners of the Catholic faith, we come to the problem of explaining the Inquisition as the powerful social control force that it was. Certainly the Church was able to make its label stick and enforce its rules. The hunting, tagging and slaughter of large segments of the population of Europe were the consequences of the Church's particular creation of deviance.

Christianity had conquered the peasant population, at least in part, as the people were forced to accept the Church's sacraments, whether they liked it or not. Until the Inquisition, however, they had simultaneously clung to their old customs. But, just as the Jews in later Hitlerian Germany and Stalinist Russia were forced to denounce their religion or die, the masses of peasants in Europe in the Middle Ages were forced by the wave of repression to accept the Church label of witches as deviant. The priestesses of the Old Religion, who refused the label, tried to evade persecution. Escape from the stigma, as I shall document in the next section, was virtually impossible, and many innocent victims were sacrificed.

The crime for which these women died was called Witchcraft. Few of those who perished were Wiccan. For, the Wiccan had gone underground and its priestesses and priests had faced the almost impossible sacred labor of preserving the Old Religion (McFarland, 1957:42). 


\section{The Relative Power of Christianity and the Old Religion}

For a more complete explication of the campaign of terror against witches, we need to consider the relationship between Christianity and the Old Religion in terms of relative power.

As the twelfth century drew to a close, the Church was approaching a crisis in its career. The vicissitudes of a hundred and fifty years, skillfully improved, had rendered it the Mistress of Christendom. History records no such triumph of intellect over brute strength as that which, in an age of turmoil and battle, was wrested from the fierce warriors of the time by priests who had no material force at their command, and whose power was based alone on the souls and consciences of men. Over soul and conscience their empire was complete. No Christian could hope for salvation who was not in all things an obedient son of the Church, and who was not ready to take up arms in its defense; and, in a time when faith was a determining factor of conduct, this belief created a spiritual despotism which placed all things within reach of him who could wield it (Lea, 1906 v. I:1).

Without looking into the question of whether the "barbarian hordes" had spread their religion by force, we can establish the fact that it had spread. It had remained in the countryside throughout Europe as Christianity also spread. But Christianity, as has been noted, institutionalized itself in league with the ruling classes, amassing substantial wealth and power. By the time the beliefs of the Old Religion reached the cities, "strongholds of Church and State, they were up against a sizable power structure. Cohn traces followers of the so-called heretical sects as

... they began to spread along the trade routes from the Balkans and to proliferate in the developing urban civilizations of northern Italy, France, and the Rhine Valley, finding their adherents first among the nobles and clergy, and then among the merchants and artisans. The authorities, both ecclesiastic and secular, reacted sharply to these signs of organized dissent. The easy-going pragmatism of earlier centuries gave place to a growing intolerance and rigidity in matters of faith. Heretics were burned, but that was not enough; very soon they were being defamed as well. It was in the context of this struggle against heresy that, for the first time in Western Europe, groups of human beings were described as Satan-worshippers (1970:8) .

A very important feature of the creation of "heretical sects" is the stereotypic notion involved. Agents of the Church had in the past intermittently singled out heretics for excommunication and execution. Then came Luther with his Nine Theses. He had enough followers that the Church was unable to wipe them out as a group. This turned out to only strengthen the attack on the Old Religion, however, as the Protestant Church also burned witches as scapegoats. Nevertheless, the focus here is on the Catholic Church as it carried on the Early Christian teachings.

With the social, economic and political power it had amassed by 1300 , the Church could make the jump from the concept of the heretic as an individual rejecting her/his Christian belief and embracing a contrary one to the concept of a "heretical sect;" that is, a religious group which rejects Christianity and, in this case, takes the Devil as its God:

What the Inquisition did was to interpret these age-old popular beliefs in terms of Satan-Worship. In doing so they created the stereotype of the witch as a man or woman who has voluntarily entered into Satan's service, and who has received in exchange the power to harm human beings in their property or their lives. . . : In this way the Inquisitors built up the fantasy of a mysterious sect, endowed with supernatural powers, which at Satan's bidding was waging incessant war on Christians and Christendom (Cohn, 1970:11).

\section{The Height of the Inquisition}

The claim being made is that the Church, as the institutionalized embodiment of one religion, used a process of stigmatization and oppression to destroy another religion. This is 


\section{Mid-American Review of Sociology}

probably best summarized in the words of Pope Innocent VIII, whose Bull of 1484, "Summis desiderantes," marks the beginning of the "no-holes barred" phase of the Inquisition:

Desiring with the most heartfelt anxiety, that the Catholic Faith should especially in this Our day increase and flourish everywhere, and that all heretical depravity should be driven far from the frontiers and bournes of the Faithful, we very gladly proclaim and even restate those particular means and methods whereby Our pious desire may obtain its wished effect, since when all errors are uprooted by Our diligent avocation as by the hoe of a provident husbandman, a zeal for, and the regular observance of, Our holy Faith will be all the more strongly impressed upon the hearts of the faithful (Summers, 1927:533).

Let us try to draw out some elements of the witch image as created by the Church Fathers and their exuberant servants, the Inquisitors. We can look at the mythology surrounding the witch-image, the accusations and definitions of crimes, and methods or proving witchcraft in comparison to some anthropological interpretations of rites and practices of the Old Religion. Kors and Peters say that

...the theological and liturgical framework of witch beliefs insisted that the agreements which bound a witch to Satan were a perversion of those rites which bound a soul to God-hence the frequent mention of perverted sacraments and offenses committed upon religious objects $(1972: 148)$.

In addition to a sort of evil baptism, the pact with the Devil was sealed by sexual intercourse. As to the baptism, it is understandable in terms of religio-centrism that the model of Christian reality would be used to paint a picture of heathen heresy. Concerning the consummation of the Devil's Pact, this aspect may have resulted from the dismay of the Church at the depravity of fertility cult celebrations. As mentioned earlier, sexual acts were integral parts of their rituals (Cohn, 1970:9-11).

\section{Labeling and Oppression}

Upon selling her soul to the Devil, the witch was supposed to be bestowed with magical powers. These included powers of healing as well as harming, and powers to influence crop growth and to predict the future. Those who could predict the weather were called tempestraii. These powers are among those actually claimed by the real Wiccan. The Inquisition simply defined them as having evil, rather than sacred, causes and effects, and broadened the category to include astrologers, palmists, psychics and others (Pratt, 1915:36-37).

The outstanding feature of accusations and trials is that witches were condemned as having practiced any kind of magic, not just black magic. Thus as Michelet tells us,

The Church ... declares, in the fourteenth century, that if a woman dare to cure without having studied, she is a witch and must die (1939:xix).

Women healers had studied, of course, but they had studied their own experience, nature and folklore. They had not, like the physicians of the period, qualified themselves for medical practice by studying philosophy and theology (Garland, 1949; Dawson, 1935; Michelet, 1939). These university-trained physicians contributed testimony used to convict mid-wives and lay healers of witchcraft.

The "logic" of the Church's position is:

... a sickness could not be removed except by a person who had caused it; for no one might thrust his sickle in another's harvest, according to the law which provides that he who binds must also unbind...

... no one who had been bewitched could be restored to health unless his sickness were even more grievously transferred to another; and that the sickness always grew in these exchanged...

... such restorations to health were never absolute and complete, but that there always remained some trace of the sickness... 
... it was useless to look for any alleviation or cure of a sickness from those who had been brought to trial for witchcraft; for all such power had then passed into the hands of the devil, who is able to perform all such things (Guazzo, 1929:121-122).

By these guidelines for witch persecution, the Compendium Maleficarum pronounced that women healers were witches because: 1) a cure could only be rendered by the person who caused the disease, and all diseases were caused by the Devil or his human servants; 2) upon lifting the sickness from one person or animal, the witch put it in another; 3 ) the cure was not "real;" and 4) such cures as were reported could not be performed after the witch's imprisonment, because she by then had craftily slipped her powers back to the Devil from whence they had come. This last apology for lack of evidence cleared the way for Inquisitors to convict on hearsay and justify torture for confessional proof, since no first-hand evidence was to be had.

It deserves to be mentioned that, in addition to the fact that white magic was equated with black magic, there was no distinction made among crimes of varying severity insofar as punishment was concerned. Thus, in earlier centuries, seven years' penance had been given to "those who confessed of causing havoc by creating storms as well as to those who, through their magical devices, were convicted of injury or murder" (Pratt, 1915:35). But in later centuries, death by burning "quick" (while the victims was still alive) could be ordered for helping or healing (if "shown" to be done by divination) and sorcery or magic of any kind not condoned by the Church.

The witch fever at its height became so strong that many secular trials for fraud, robbery and murder, as well as "immorality", were tried in ecclesiastical courts. "All witches were criminals and all criminals were witches" seems to describe the Inquisition mentality. In most cases, the death sentence as well as the condemnation to the tortures and atrocities of everlasting Hell were imposed on the act not because it constituted an infraction of a rule, but because the act possessed some abstract quality of evil.
Upon making their evil agreements with the Devil, witches were said to be given a mark on some part of the body, usually a part hidden by clothing. The "Witches' Mark" or "Devil's Mark," it was claimed, was numb and did not bleed when pricked. Murray looks for factual explanation of such marks and concludes:

Local anesthesia is vouched for on much of the evidence, which suggests that there is a substratum of truth in the statements, but I can at present offer no solution to this problem (1921:86).

From the evidence five facts are clear: (1) that the mark was colored, (2) that it was permanent, (3) that it was caused by the pricking or tearing of the skin, (4) that the operator passed his hands or fingers over the place, (5) that the pain could be severe and might last a considerable time. Put together in this way, the facts suggest tatooing (1921:87).

Witch-finders developed a technique, using a special instrument, of pricking accused women all over their bodies until a spot might be found which when pricked produced no bleeding or expression of pain from the accused. If the victim did not bleed to death during the process, she might confess to her judges to avoid the agony. Such confessions under torture were fairly common, as Inquisitors often promised leniency or absolution in exchange for them. This was rarely given, however (Szasz, 1970:36-38).

Another manifestation of the "Devil's Mark" was the "witch-pap" or "little Teat." This was described as a third nipple, smaller than the two normal ones, which secreted milk and functioned to nurse the witches' "familiars," demons in animal form. This was very likely another case of a real object or condition being bestowed with attributed of evil.

The descriptions of the "teat" point to its being that natural phenomenon, the supernumerary nipple. Cases of polymastia, or supernumerary breasts, and of polythelia or supernumerary nipples are constantly recorded by modern medical observers. These accessory structures are usually situated on the chest wall, the 
upper part of the abdominal wall, or on the shoulder, the buttocks, the thigh, and other extraordinary positions. As a rule, they are functionless. Polythelia occurs in both sexes (Murray, 1921:90).

Because polythelia was not an infrequent condition, and because it was the ultimate stigma, those unfortunate peasants possessing supernumerary nipples tried to cut them off when they found out that that the Inquisition was coming to town. So we see testimonies given by examiners to the effect that the accused had on her body a bloody sore, which indicated she had tried to hide her guilt by severing the evil organ. She was damned if she did and damned if she didn't. Also, there developed the notion that the Witches' Mark could be invisible, could change form and color, could be painful some times and not others, but nevertheless could be located by certain skilled witch-finders. The testimony of such a person could result in a conviction (Szasz, 1970:32-33).

The "familiars" were supposed to be demons in various animal forms given to a witch by her Master to aid in her diabolic ministrations. The familiars, as already mentioned, were suckled by the witch and were also objects of her sexual lust. Murray and others attribute this aspect of the witch-image to a distortion of customs of the Old Religion. Its priests and priestesses often tried to represent their gods in animal form, either by dressing in skins of animals, or by using drugs to induce euphoric states in which they envisioned themselves and each other in such forms.

In France, where the solemn sacrifice of a goat at the Sabbath points to that animal being sacred, it is not surprising to find both men and women witches appearing as goats and sheep.... It would seem that the witches, like the adorers of animal gods in earlier times, attempted to become one with their god or sacred animal by taking on his form; the change being induced by the same means and being as real to the witches as to Sigmund the Volsung or the worshipper of Lycaean Zeus.

In the earlier cults the worshipper, on becoming an animal, changed his outward shape through the eye of faith alone, though his actions and probably his voice proclaimed the transformation. The nearest approach to an outward change was by covering the body with the skin of the animal, or by wearing a part of the skin or a mask. The witches themselves admitted that they were masked and veiled, and the evidence of other witnesses goes to prove the same (Murray, 1921-230-231).

By the height of the Inquisition, in the fourteenth and fifteenth centuries, the Church concentrated more on convicting witches for being witches, but had already built up an entire body of mythology about what it was that witches did. At the center of this fantasy was the witches' Sabbath. The witches flew to the Sabbath at midnight, the "witching hour," on broomsticks accompanied by their familiars. At the Sabbath they sacrificed dead babies which they had dug up from graves or stolen from women in childbrith when they acted as midwives. The infants were roasted and eaten. The feast was followed by sexual orgies involving the witches, their familiars and the Devil (Guazzo; 1929:33-50).

Without the attachments of evil connotations and attributes, the above passage roughly fits the description of a fertility cult worship ceremony. The faithful would ingest hallucinogenic substances or anoint themselves with unguents concocted from such substances. They would then indeed "fly" (or trip) to their worship-place, where human sacrifices were made. There was feasting, although not on dead babies, and there were religious sexual celebrations, or "orgies." These pagan rituals were easily transformed into hideous acts with the imposition of Christian values (Murray, 1952:96-124; Summers, 1956:110-172).

The pricking test has already been described. Although it was at least based in the mythology of the witch-image, other tests consisted mainly of the Inquisitors' questioning the accused until they admitted their crimes. This interrogation was aided by the use of torture. In many cases, the wretched conditions of imprisonment and starvation, the living Hell experienced by those awaiting "examination," made them eager to confess. Death was a welcomed relief from suffering. 
Other evidence consisted of testimony by those who had been bewitched. Such testimony was not too difficult to obtain, since it at least temporarily secured immunity from prosecution for those who gave it. This was the case until the Church began to condemn the bewitched to the same fate as the witches. The Church, after a time, had defined the pervasiveness of evil due to witchcraft in such a way that the Inquisitor's accusation was, in effect, a death sentence.

It is not necessary to describe the various types of torture used in order to point out the role of torture in obtaining confessions. These confessions from the victims gave the Church credibility, at least as interpreted by its apologists. Torture was justified by the following rationale:

... But what we are to consider now is what action the Judge should take, and how he should proceed to question the accused with a view to extorting the truth from her so that sentence of death may finally be passed upon her.

And here, because of the great trouble caused by the stubborn silence of witches, there are several points which the Judge must notice ... And the first is ... unless God, through the holy Angel, compels the devil to withhold help from the witch, she will be so insensible to the pain of torture that she will sooner be turn limb from limb than confess any of the truth (Sprenger and Kramer, 1928:223) .

\section{Internal Criticism of the Inquisition}

It is difficult to imagine the Church, even with the dominance it enjoyed at the height of the Inquisition, being able to subject millions of people to torture and burning at the stake without triggering some sort of dissent among its hierarchy, if not open rebellion among the people. There were, in fact several laymen and theologians who themselves risked burning as heretics by challenging the myth of witchcraft. Among the most famous of these was Reginald Scot, whose Discoverie of Witchcraft presented in 1584 a perspective quite similar to the one presented in this paper. Frederic von Spee, an Inquisitor who had executed 200 witches in a four year period, wrote Cautio Criminalis in 1631, in which he stated his misgivings about his job. Pratt summarizes them thusly:

Spee says that torture fills the land with witches, because the torments are so frightful that many confess crimes they have not committed; women especially are prone to accuse themselves falsely. Persons who, under torture confess falsely, are not guilty of mortal sin. According to the author, witch-marks are not to be taken as a sign of guilt; 'I did not see any and do not believe in them and I deplore the shameful credulity of so many distinguished men in this regard' (Pratt, 1915:79).

Spee's teacher, the Jesuit theologian Adam Tanner, published Universa theologica scholastics, speculativa, practica ad methodum sancti Thomae in 1626, in which he pleaded for an offender advocate program for those accused of witchcraft and for the elimination of confessions extracted through torture as evidence. $\mathrm{He}$ also asked that penitent witches not be burned. He very tellingly urged that only "the most intelligent" judges be employed (Pratt, 1915:78).

But the dissidents had little effect, as the victims who could not read their books could not rally around their cries. The Church hierarchy suppressed such works and the Inquisition was allowed to play itself out. The Church held itself above criticism, insisting that it was about the business of salvation. The "PressingDanger," as witchcraft was called by Pope Eugenius IV (Kors and Peters, 1972:v), was real and imminent. The Inquisitor Bernard of Como gave an exemplary defense:

'This is proved,' he says, 'from the fact that the Popes have permitted the witches to be burned at the stake; they would not have countenanced this, if these persons were not real heretics and their crimes only imaginary, for the Church only punishes proved crimes' (Pratt, 1915:108). 
Mid-American Review of Sociology

Self-grounded authority, then, was the answer to criticism of the Church. Church dogma fairly reeks of beneficent language intended to take the edge off what is actually being said. For example, the Church answers the criticism of using torture by saying that "torture was not of ecclesiastical origin" (Pratt, 1915:105), and by pretending to discourage it. Pope Innocent IV was the first to actually authorize torture, in his Bull, $A d$ exstirpanda of 1252:

The Bull of Innocent IV states that 'the podista (ruler) is ordered to force all captured heretics to confess and accuse their accomplices by torture, which must not imperil life or injure limb...' (Pratt, 1915:109).

The Church was not to be held directly responsible for the actual executions, since these were technically done by secular authorities. The Church's apologia to the condemned woman was that she was being "abandoned" or (even more mercifully put) "relaxed" to the secular arm. Church officials were free to promise not to execute a defendent if she would confess her guilt, because they fully intended to "abandon" her to the secular authorities who did the actual lighting of the torch (Sprenger and Kramer, 1928:23).

\section{Contemporary Significance of Witchcraft and the Inquisition}

The greatest reward to be gained from looking back through history is a stimulation to view the present critically and imagine the future-to search for and delineate historical implications for current theory and research. Certainly the image of woman as witch, as evil incarnate, has persisted through the years and across cultures. It is counterposed by the image of woman as virginal and saintly, creating duality of definition. Institutionalized religion continues to hold up both images, worshiping the normative while excoriating the deviant. Womens' struggle for recognition within the Church is a reminder of the fact that institutionalized religion continues to be controlled by a patriarchy. However, the roots of
Labeling and Oppression

oppression have grown from secular as well as sacred soil, and are entangled in the foundations of all contemporary institutions. Woman is still considered an anomoly by the power-wielding descendants of Church, State, and Medicine.

Sociologists are beginning to seriously address the position of women today. While we are counting heads to determine how many of "them" are infiltrating the lower echelons of the power elite, let us not forget to imagine the impact of a label that has persisted over centuries. We cannot ignore the psychology of oppression any longer.

Let us dig out and examine the image of woman as temptress, directed by Satan and beguiling man. Has woman's "power" as sex object brought her into a situation of control over man? Or is woman's body, as well as her mind, controlled by male-defined medical technology and treatment methods, by male-defined church doctrine, by male-defined media images, by male-controlled business, government and educational institutions?

Can we look at recent research on sex role socialization and find a pattern of training for female dominance? No. We find elementarily that males are socialized toward dominance, females for submissiveness (Weitzman, 1975:105-117). We find that females are getting the message that their bodily structure is inferior and it's functions obscene. Contemporary sex role socialization is more subtle than the image conveyed by witch-hunters, but it is just as powerful in perpetuating the idea that

... it is women who are chiefly addicted to evil supersitition ... all witchcraft comes from carnal lust, which is. in women insatiable (Sprenger and Kramer, 1928:47).

It is not a giant step from the words of the Maleus Maleficarum to present-day notions that women recognizing, studying, and working to eradicate sex oppression are penis enviers, ball busters, or lesbians-deviants of one sort or another. If deviant, then they are organized around a deviant identity, as 
there are movements underway for women to uncover the secrets and practices of the Wiccan, to reclaim herbal medicines and natural cures, and to organize self-health groups and bring back the practice of midwifery. A "woman's culture" movement is astride. Will history continue to repeat itself? This question merits attention from the sociological imagination, the operationalization of critical variables, and a responsible analysis informed by the past and fired by hope for growth in the future.

\section{NOTES}

1. Studies such as those done by Evans-Pritchard on African tribal cultures characterize a dominant anthropological approach to the topic. A good collection of essays from this perspective can be found in Mary Douglas, editor, Witchcraft: Confessions and Accusations. The most outstanding representative of the psychopathological view of the witch phenomenon seems to be Gregory Zilboorg, The Medical Man and the Witch During the Renaissance. A modern work with a cross-cultural examination from the same perspective is Ari Kiev's Magic, Faith and Healing. Two pieces that differ somewhat in perspective but are similar in their treatment of witches as an oppressed group rather than an agglomeration of individual deviants are Thomas S. Szasz, The Manufacture of Madness, pp. 3-134 and Barbara Ehrenreich and Deirdre English, Witches, Midwives and Nurses: A History of Women Healers, pp. 6-20. Both inspired the present inquiry.

2. The selection of this time and place for study is not made just for the sake of convenience. Europe in the Middle Ages gave the world the infamous Inquisition, during which it is established that millions of heretics and witches were burned. Indeed, it was the Inquisition that made these two epithets, heretic and witch, synonymous. I would like to note also that attention is not given in this paper to many victims of Inquisition, such as Jews, homosexuals, and others whose story needs to be told.

\section{REFERENCES}

Becker, Howard S.

1963 Outsiders: Studies in the Sociology of Deviance. New York: The Free Press.
Cohn, Norman

1970 "The Myth of Satan and his Human Servants" in Mary Douglas, ed., Witchcraft: Confessions and Accusations. London: Tavistock Publications.

Dawson, George Gordon

1935 Healing: Pagan and Christian. London: Society for Promoting Christian Knowledge.

Douglas, Mary

1970 "Introduction: Thirty Years After Witchcraft, Oracles and Magic" in Mary Douglas, ed., Witchcraft: Confessions and Accusations. London: Tavistock Publications.

Ehrenreich, Barbara and Deirdre English

1973 Witches, Midwives and Nurses: A History of Women Healers.

Garland, Joseph Old Westbury: The Feminist Press.

1949 The Story of Medicine. Boston: Houghton Mifflin, Co.

Guazzo, Brother Francisco Maria

1929 Compendium Maleficarum (1605). Edited with notes by the Reverand Montague Summers, translated by E.A. Ashwin. London: John Rodker.

Kiev, Ari

1964 Magic, Faith, and Healing: Studies in Primitive Psychiatry Today. New York: The Free Press.

Kors, Alan C. and Edward Peters

1972 Witchcraft in Europe 1100-1700: A Documentary History. Lea, Henry Charles Philadelphia: University of Pennsylvania Press.

1906 A History of the Inquisition of the Middle Ages, Volumes I-III. New York: The Macmillan Company.

McFarland, Morgan

1975 "Witchcraft: The Art of Remembering." Quest: A Feminist Quarterly 1 (Spring):41-48.

Michelet, Jules

1939 Satanism and Witchcraft: A Study of Medieval Superstition. New York: The Citadel Press.

Murray, Margaret Alice

1921 The Witch-Cult in Western Europe. Oxford: Clarendon Press.

1952 The God of the Witches. London: Sampson Low, Marston \& Co., Ltd.

Pratt, Sister Antoinette Marie, A.M.

1915 The Attitude of the Catholic Church Towards Witchcraft and the Allied Practices of Sorcery and Magic. Washington, D.C.: National Capitol Press. 
Mid-American Review of Sociology

Russell, Jeffrey Burton

1972 Witchcraft in the Middle Ages. Ithaca: Cornell University Press.

Sprenger, Jacob and Heinrich Kramer

1928 Malleus Maleficarum (1486). Translated with an introduction, bibliography and notes by the Reverend Montague Summers. London: John Rodker.

Summers, Montague

1927 The Geography of Witchcraft. London: Kegan Paul, Trench Trubner \& Co., Ltd.

1956 The History of Witchcraft and Demonology. New York: University Books.

Szasz, Thomas S.

1970 The Manufacture of Madness. New York: Dell.

Weitzman, Lenore J.

1975 "Sex Role Socialization" in Jo Freedman ed., Women: A Feminist Perspective. Palo Alto, Calif.: Mayfield.

Zilboorg, Gregory

1941 A History of Medical Psychology. New York: W.W. Norton and Co.
NOTES AND COMMENTS

\section{SOCIOLOGICAL IMPLICATIONS OF THE HABERMAS-RELATED SECOND GENERATION OF THE FRANKFURT SCHOOL: A BIBLIOGRAPHIC ESSAY}

\section{Richard R. Weiner}

University of North Florida

The tradition of the Critical Theory of Society developed by the Frankfurt.School has been renewed by a second generation. Most prominent among them is JürgenHabermas and his colleagues Karl Otto Apel and Alfred Schmidt. Also of significance are both the dialogues and debates between Habermas and his students: Claus Offe, Oskar Negt and Bernard Willms.

The specific themes argued by the Frankfurt School diverge from their chosen paradigm-Marx's critique of political economy. Fundamentally, Critical Theory radically revised the terms of Marx's analysis, redirecting its focus from the infra-structure to the superstructure, replacing the critique of political economy with the critique of instrumental rationality. They sought to perceive simultaneously the combined effects of constitutive objective-historical conditions of domination and constituting subjective-intentionality of practical reasoning.

For the Frankfurt School, the existing relations of production came to be seen as that form of organization which is technically necessary for a rational society, while all social problems had been made to seem to be questions of technical adjustment. In the Dialectic of Enlightenment Horkheimer and Adorno emphasize the emergent modern conflict between two concepts of reason. Practical reason is grounded in deliberation and dialogue over the conditions of the good life. Instrumental reason is found in the technical control of nature.

In this vein Habermas distinguishes between instrumental and communicative action. In instrumental action we encounter objects the paradigm for which are moving bodies, capable of 